Nigerian Journal of Physiological Sciences 22 (1-2): 135-139 @Physiological Society of Nigeria, 2007

Available online/abstracted at http://www.biolineinternational.org.br/njps; www.ajol.info/journals.njps; www.cas.org

\title{
CORRELATION OF HISTOLOGICAL AND HISTOMETRIC CHANGES IN RATS TESTES TREATED WITH CHLOROQUINE PHOSPHATE
}

\author{
O. R. ASUQUO ${ }^{1}$, A. O. IGIRI ${ }^{1}$, O. O. OLAWOYIN ${ }^{2}$, E. U. EYONG ${ }^{3}$
}

\author{
Department of Human Anatomy ${ }^{1}$, Department of Animal Science ${ }^{2}$, Department of Biochemistry ${ }^{3}$, \\ University Of Calabar, Calabar Cross River State - Nigeria \\ Tel:08075051562E-mail: olaasuquo@yahoo.com
}

\begin{abstract}
Summary: Histological and histometric changes in the testes of albino Wistar rats were correlated. Wistar rats weighing between $180-240 \mathrm{~g}$ were randomly divided into three groups of ten rats each. One group served as control and the rats were given normal saline. The second and third groups received $2 \mathrm{mg} / \mathrm{kg}$ and $4 \mathrm{mg} / \mathrm{kg}$ body weights of chloroquine phosphate daily for thirty days respectively. Seminiferous tubules of animals treated with chloroquine phosphate were irregular in shape and were also isolated compared to control. Marked disruption of the inter-tubular stroma of testes in the treated groups was also observed. Histometric variations in testicular tissue was observed in the experimental animals following treatment with chloroquine phosphate. The $2 \mathrm{mg} / \mathrm{kg}$ body weight and $4 \mathrm{mg} / \mathrm{kg}$ body weight animals recorded significantly lower $(\mathrm{P}<0.05)$ relative germinal epithelial volume of $43.95 \%$ and $32.70 \%$ respectively when compared to the control $(51.75 \%)$. The volume of stroma in the third group $(49.33 \%)$ was significantly higher $(\mathrm{P}<0.05)$ when compared to the control $(16.83 \%)$ and $2 \mathrm{mg} / \mathrm{kg}$ body weight rats $(22.83 \%)$. We observed negative correlation coefficient between lumen and seminiferous tubular volume in the control group compared to the other groups which showed a positive correlation. Correlation between germinal epithelium and seminiferous tubular volume were positive in all groups. These findings have thrown more light on recognized histological changes by accurately grading these changes which offers objectivity and increased precision compared with direct visual appraisal.
\end{abstract}

Key Words: Seminiferous tubules, Inter-tubular stroma, Chloroquine phosphate, Testes, Correlation

Introduction

Malaria affects more than 2.4 billion people, over $45 \%$ of the World's population in more than 100 countries in the tropics (Winstanley and Breckenridge, 1987). About $90 \%$ cases of malaria occur in sub-Saharan Africa where the disease contributes substantially to underdevelopment and places a severe strain on limited health care facilities (Wernsdorfer and McGregor, 1988). The disease has spread into new areas as a result of changing land utilization, especially plantation agriculture and this has led to epidemics in regions previously free of malaria (Trigg and Kondrachine, 1998). About 110 million clinical cases occur annually with about 1 million deaths yearly (WHO, 1990).

Chloroquine is a synthetic derivative of 4amino quinoline. Inspite of reported cases of chloroquine resistance to the malaria parasites, it is one of the drugs of choice for the control and cure of malaria (Bisseru, 1985). Apart from its anti-malarial activity, chloroquine is useful in the treatment of gastro intestinal ameobiasis, systemic lupus erythematosis, fluke infection, discoid lupus erythemaosis and rheumatoid arthritis (Huskinsson, 1979). Literature abounds on the adverse effects of chloroquine on tissues (Laurence and Benneth 1986; Ratcliff et al, 1989; Okpako and Azoba, 1989, Warhurst et al, 1996; Ebong et al, 1999). Adverse reactions to chloroquine include rashes, itching and other allergic reactions (Rook et al, 1972). Others include convulsion, nausea, vomiting, abdominal cramps and greying of the hair (Kasilo, 1988).

Histometry is suitable for histological investigation since it offers objectivity and increased precision compared with direct visual appraisal, and makes statistical analysis easier (Ahmad et al, 1989). Histometry is also valuable when abnormalities are recognizable by eye but an accurate grading of changes is required, (Dunhill and Whitehead, 1972; Chalkey, 1973). Investigation by Ashiru et al (1991) had shown a reduction in tubular length 
and diameter of seminiferous tubules. The present study was designed to correlate recognized histological changes and histometric grading of changes following prolonged administration of chloroquine to male Wistar rats.

\section{Materials and Methods}

Thirty male Wistar rats weighing between $180 \mathrm{~g}$ and $240 \mathrm{~g}$ were bred in the animal house of the Department of Anatomy, University of Calabar. The animals were divided into three groups (A, B and C) of ten rats each. Group A served as control and was administered normal saline. Groups B and C were administered $2 \mathrm{mg} / \mathrm{kg}$ and $4 \mathrm{mg} / \mathrm{kg}$ body weights of chloroquine daily for 30 days respectively. The drug was orally administered with the aid of a gastric tube.

The testes from all experimental groups were collected, fixed in $10 \%$ buffered formalin solution, dehydrated in a graded series of ethanol and embedded in paraffin wax. Samples were sectioned at 5 thick on a rotary microtome, mounted on glass microscope slides with DPX and stained with haematoxylin and eosin. Through direct microscopy, relative volume percentage of the germinal epithelium, stroma and lumen of seminiferous tubules and average thickness $(\mu \mathrm{m})$ of seminiferous tubules were evaluated with respect to each group. For relative volume, a system of parallel lines (eye graticule) was placed over the section and the length of the line which lies within the structure of interest was measured. This length expressed as a proportion of the total length of the line falling over the tissue is equal to the area proportion of the structure and thus the volume proportion. For length and diameters, the eye piece and stage micrometer were parallelized through slide rule method and equivalent length on the stage micrometer to the number of division of eye graticule was determined. The data obtained was presented as Mean \pm standard deviation. Analysis of Variance (ANOVA) was used to evaluate the differences between the groups. Pairwise comparison was done using the student's t-test and values of $\mathrm{p}<0.05$ were regarded as significant.

Table 1: Histometric characteristics of the rats testes in the various groups

\begin{tabular}{lccc}
\hline \multicolumn{1}{c}{$\begin{array}{c}\text { Histometric } \\
\text { parameters }\end{array}$} & $\begin{array}{c}\text { Group A } \\
\text { (control) }\end{array}$ & $\begin{array}{c}\text { Group B } \\
(2 \mathrm{mg} / \mathrm{kg} \mathrm{b} . \mathrm{w})\end{array}$ & $\begin{array}{c}\text { Group C } \\
(4 \mathrm{mg} / \mathrm{kgb} . w)\end{array}$ \\
\hline $\begin{array}{l}\text { Germinal epithelium } \\
\text { Rel vol \% }\end{array}$ & $51.75 \pm 5.65$ & $43.95 \pm 2.39$ & $32.70 \pm 4.25^{\mathrm{b}}$ \\
$\begin{array}{l}\text { Stroma Rel vol \% } \\
\text { Lumen Rel vol \% }\end{array}$ & $16.83 \pm 1.97$ & $22.83 \pm 2.47^{\mathrm{a}}$ & $49.33 \pm 4.01^{\mathrm{b}}$ \\
$\begin{array}{l}\text { Seminiferous tubules } \\
\text { Rel. vol \% }\end{array}$ & $82.33 \pm 2.38$ & $77.17 \pm 2.47^{\mathrm{a}}$ & $50.67 \pm 4.01^{\mathrm{b}}$ \\
$\begin{array}{l}\text { Seminiferous tubular } \\
\text { length }(\mu \mathrm{m})\end{array}$ & $296.25 \pm 32.35$ & $326.25 \pm 32.80$ & $293.75 \pm 30.91$ \\
$\begin{array}{l}\text { Seminiferous tubular } \\
\text { diameter. }(\mu \mathrm{m})\end{array}$ & $158.75 \pm 12.14$ & $189.38 \pm 8.81$ & $174.38 \pm 10.61$ \\
\hline
\end{tabular}

Values are mean $\pm \operatorname{SEM}(n=10)$

$a$ - Significantly different from control at $p<0.05, b$ - Significantly different from control at $p<0.01$

Table 2: Correlation Analysis of Histometric structures of the testes at the Group level.

\begin{tabular}{lccccc}
\hline Parameter & Group & $\mathrm{ST}_{\mathrm{v}}$ & $\mathrm{ST}_{1}$ & $\mathrm{Lu}$ & $\mathrm{GE}$ \\
\hline $\mathrm{GE}$ & $\mathrm{A}$ & $0.621^{\mathrm{a}}$ & -0.427 & $-0.913^{\mathrm{c}}$ & \\
& $\mathrm{B}$ & 0.233 & -0.058 & $-0.602^{\mathrm{a}}$ & - \\
$\mathrm{LU}$ & $\mathrm{C}$ & $0.593^{\mathrm{a}}$ & -0.032 & -0.502 & \\
& $\mathrm{~A}$ & -0.247 & 0.266 & & \\
& $\mathrm{~B}$ & $0.636^{\mathrm{a}}$ & 0.262 & - & \\
$\mathrm{ST}_{1}$ & $\mathrm{C}$ & 0.399 & 0.312 & & \\
& $\mathrm{~A}$ & -0.502 & & & \\
& $\mathrm{~B}$ & 0.375 & - & & \\
& $\mathrm{C}$ & 0.257 & & & \\
\hline
\end{tabular}

GE - germinal epithelium, $L u$ - lumen, $S T_{v}$ - semineiferous tubular volume, $S T_{1}$-seminiferous tubular length, a - significant at $p<0.05, b$ - significant at $p<0.01, c \quad$ - significant at $p<0.001$ 


\section{Results}

Histological observations revealed well defined seminiferous tubules in the testis of control rats. Numerous elongated Leydig cells when viewed individually were also present as well as Sertoli cells.(Fig 1) In group B treated with chloroquine phosphate, the seminiferous tubules were irregular, Immature spermatozoa were seen lying in the lumen of seminiferous tubules accompanied by cell debris (Fig. 2). In group $\mathrm{C}$ rats seminiferous tubules appeared as isolates, Leydig cells were lost, with marked disruption of inter-tubular stroma as compared with the control was also observed (Fig 3).

Variations in testicular tissue has been observed in experimental animals following treatment with chloroquine phosphate. Groups B and C recorded significantly lower $(p<0.05)$ relative germinal epithelial volume $(43.95 \%$ and $32.70 \%$ respectively) when compared to control $(51.75 \%)$. However, the volume of stroma in group C $(49.33 \%)$ was significantly higher $(\mathrm{p}<.005)$ than in group A $(16.83 \%)$ and group B
(22.83\%). The volume of seminiferous tubular lumen $(17.96 \%)$ as well as the volume of the tubules (50.67\%) were significantly lower $(p<0.05)$ in group $C$ animals when compared to controls which recorded relative seminiferous tubular lumen volume of $30.58 \%$ and a relative tubular volume of $80.33 \%$. The seminiferous tubular lengths and diameter of the test groups were not significantly different from controls (Table1).

Table 2 shows correlation in the testis found in each group. A negative relationship was found between lumen and seminiferous tubular volume in group A (0.247) compared to groups $B$ and $C$ which showed a positive correlation of 0.636 and 0.399 . Correlation between seminiferous tubular volume and seminiferous tubular length showed a positive result in groups B and C (0.375 and 0.257) compared to group A which was negatively correlated $(-0.502)$. Correlation between germinal epithelium and seminiferious tubular volume were all positive in all groups with group A having the highest value of 0.621 .

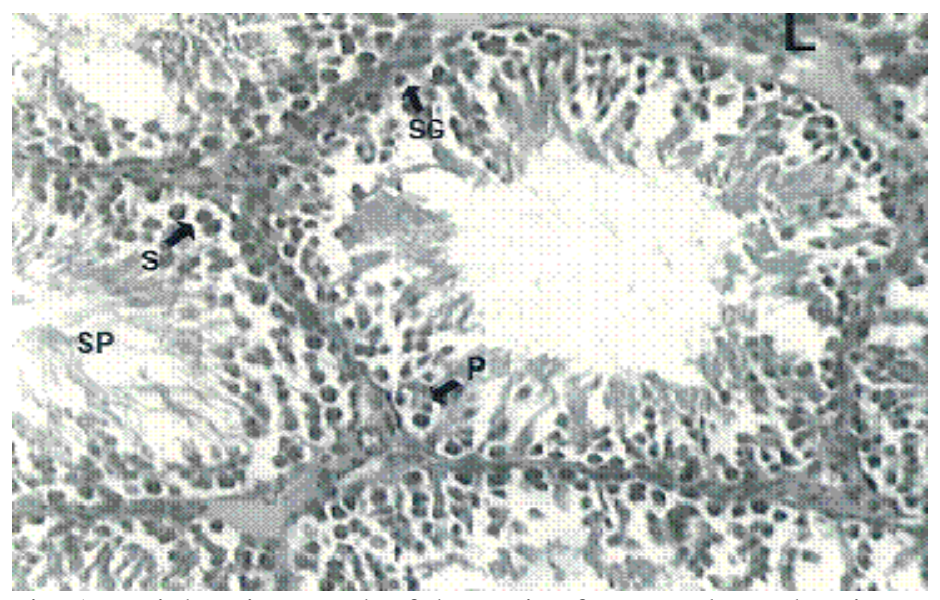

Fig. 1: Light micrograph of the testis of a control rat, showing normal spermatogenic features $\mathrm{P}=$ primary spematocytes; $\mathrm{SG}=$ spermatogonia, $\mathrm{S}=$ sertoli cells, $\mathrm{L}=$ Leydig cells; $\mathrm{Sp}=$ spermatids and spermatozoa. (H \& E Stain x 400).

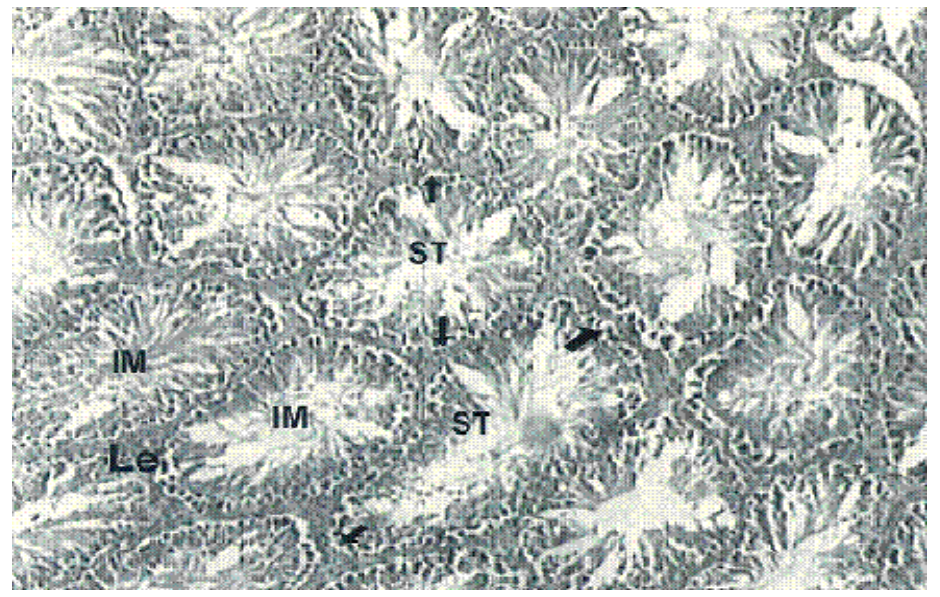

Fig. 2: Light micrograph of the testis of phosphate treated $(2 \mathrm{mg} / \mathrm{kg})$ rat shurs irregularly shaped seminiferous tubules (ST), immature spermatozoea (IM) and less Leydig cells (Le). (H \& E stain $\times 250$ ) 


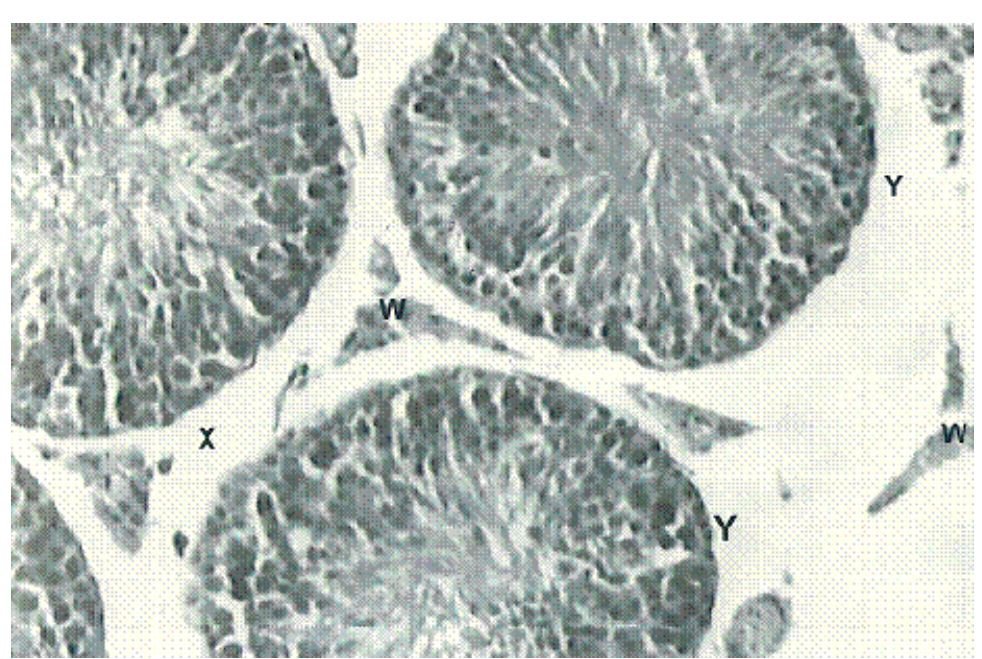

Fig. 3: Light micrograph of the testis of Chloroquine phosphate treated $(4 \mathrm{mg} / \mathrm{kg})$ rats, showing degeneration of interstitial tissues (x), loss of Leydig cells $(w)$ and seminiferous tubules appear as isolates $(Y)$. ( $H \&$ E stain $x 400)$.

\section{Discussion}

The use of chloroquine for the chemotherapy of malaria in Nigeria and parts of the tropics poses a problem of chloroquine accumulation in the kidney,liver and spleen, and its attendant toxic effect, (Adelusi et al, 1982; Gustaffson et al, 1983; Jaeger et al, 1987; Thomas,1989; Bray et al 1999). Degeneration and regression of interstitial tissues and Leydig cells have been observed following treatment of rats with test doses of chloroquine. A decrease of androgen biosynthesis is therefore expected since these cells are the primary source of the male sex hormones. These results are in agreement with reports from other investigators who observed that chloroquine caused disruption of spermatogenesis due to insufficient production of androgens by Leydig cells, (Ebong et al, 1999). The regression observed in Sertoli and Leydig cells after treatment may suggest that chloroquine is toxic to the Sertoli and Leydig cells. Its toxicity is probably mediated via effects on the anterior pituitary. Okanlawon and Dyn (1996) had reported that chloroquine exhibits anti-proteases activity and increase trans-epithelial resistance in immature Sertoli cells. Investigators had reported that toxicants that cause damage due to their irreversibility are those that kill or genetically alter spermatogonia or Sertoli cells, (Chaplin et al,1984; Potashnik \& Abeliovich,1985; Mattison et al,1990). Zukerman(1978) had suggested that dead sperm or immotile sperm often reflect the effects of post-testicular events and also reported that sperm count and sperm morphology have been found to provide indices for the integrity of spermatogenesis. The observed degeneration of germinal epithelium, interstitial tissues, Leydig cells, inter tubular stroma and loss of most of the spermatogenic cells in this study may probably lead to inhibition of spermatogenesis.

Histometric results have also attempted to throw more light on histological observations. Reduction in the mean relative volume of germinal epithelium, seminiferous tubules and lumen were observed in the treatment groups. Inter tubular stroma was significantly increased in the test groups. These findings further explains the poor differentiation of the germinal epithelium in the experimental groups. The significant increase in the inter tubular stroma infers that most of the interstitial tissues and cells of Leydig were lost and it also supports our earlier report on morphological observation. The negative correlation observed between the lumen and seminiferous tubules in the control group was expected. This supports the work of Wrobel et al, 1998. Positive correlation observed in the test groups indicates a deviation from the normal that shows that the test drug had effects on these groups. This further explains the wider lumen observed in the seminiferous tubules of the experimental groups. IT appears that histometric characteristics of cellular components of the testis are correlated based on the duration of treatment and are also dose-dependent. We reported a loss of $50.67 \%$ volume of seminiferous tubules while a loss of $64 \%$ of mean volume of seminiferous tubules have been reported, (Ashiru et al, 1991). Other investigators have reported different histometric values, (Mori \& Christensen,1980; Hluchy,1991; Massanyi et al, 1991; Toman and Massanyi, 1997).

From the foregoing, we can safely deduce that chloroquine phosphate has adverse effects 
on the testis of Wistar rats. The histometric grading correlate with our results in changes in histological structure of Wistar rat testis.

\section{References}

Adelusi, S. A., Dawodu, A. H. an Salako, L. A. (1982). Kinetics of the uptake and elimination of chloroquine in children with malaria. Brit. $J$. Pharm. 14, 483 - 487.

Ahmad, K, N., Lennox, B. and Mack, W. S. (1989). Estimation of the volume of Leydig cells in man. Lancet ii; 461.Ashiru, O. A., Okanlawon, A. O, and Noronha, C. C. (1991). Application of the point -sample intercepts to the seminiferous tubules: eviden of decreased tubular size following chronic chloroquine administration. $J$. Scan. Microsc. (Scanning). 15, 471-497.

Bisseru, D. (1985). Chloroquine resistance in Africa. Post-graduate Doc. (Africa); 7. 58-64.

Bray, P. G., Jameh, O., Raynes, K. J., Mungthin, M., Ginsburg, H. (1999). Action of Chloroquine. T. Cell. Biol., 145, 363 - 365.

Chalkey, H. W. (1973). Method for the quantitative morphologic analysis of tissues. J. Nat Canc Inst. 4, 47-51.

Chaplin, A. E., Dutton, S. L. and Ross, M. D. (1978). The effects of ethylene glycol monomethyl ether on testicular histology in F344 rats. J. Androl. 5(5), 369-380.

Dunhill, M. S. and Whitehead, R. A. (1972). Method for the quantitation of testicular biopsy specimens. J. Clinc. Path. 25, 243.

Ebong, P.E., Eyong, E. U., Eteng, M. U. and Ukwe, C. N. (1999). Influence of chronic administration of chloroquine on Leydig cell integrity and testosterone profile of albino Wistar rats. Afr. J. Rep. Heath. 3(2), 97 - 107.

Gustaffson, L., Walker, O. and Alvan, G.(1983). Disposition of chloroquine in man after single intravenous and oral doses. Brit. J. Clin. Pharm. $15,471-497$.

Hluchy, S. (1991). Effect of long-term application of herbicides Afalon-So-WP and SYS - 67B on spermiogenesis. Agric. 37, 849-855.

Huskinsson, E. E. (1979). Penicillamine and drugs with specific action on rheumatoid arthritis. Handb Exp. Pharmacol. 56, 399-414.

Jaeger A, Sander P.H, Kopferschmitt J and Flesch F.(1987b) Clinical features and management of poisoning due to antimalaria drugs. Med. Tox. 2:242-273.

Kasilo, O. (1988). Pharmacy, drugs and toxicology. Information Source Bulletin. Issue. 14, 1-8.

Laurence, D. R and Benneth, P. N. (1986). Clinical Pharmacology $5^{\text {th }}$ edition. Edinburgh, London and New York, Churchill, Livingstone; 286-291.

Massanyi, L., Janovicova, O. and Bakitova, L. (1991). Dangerous factors of environment affecting spermatogenesis. Agric. 37, 830-848.

Received: 1/12/2007

Accepted:17/12/2007
Mattison, D,R., Plowchalk, D. R. and Meadows, M. J. (1990). Reproductive toxicity: Male and Female reproductive systems as targets for chemical injury. Med. Clin. North Am. 74(2), 391-411.

Mori, H. and Christensen, A. K. (1980). Morphometric analysis of Leydig cells in rat testis. J. Cell Biol. 84, 340-354.

Okanlawon, A. 0. and Dyn, M. (1996). Effect of Chloroquine on the formulation of tight function in cultured immature rat Sertoli cells. $J$. Androl. 17(3).

Okpako, D. T. and Aziba, P. J. (1989). A dual effect of chloroquine on muscle contraction evoked by different agents. Eur. J. Pharmacol. 183(186): 24-29.

Potashnik, G. and Abeliovich, D. (1985). Chromosomal analysis and health status of children conceived to men during or following dibromochloropropane induced spermatogenic suppression. Androl. 17(3), 291-296.

Ratcliff N.B, Esther M.C, Myes, J. L. (1989). Diagnosis of Chloroquine Cardiomyopathy by endomyocardial biopsy. N. Engl. J. Med. 316, 191-193.

Rook, A., Wilkinson, D. S. and Ebling, F. J. G. (1972). Textbook of Dermatology. $2^{\text {nd }}$ Edition Oxford; 1034 - 1056.

Thomas, N. O. (1989). Chloroquine infertility. Pharm. Wld. J. 6(7): 5.

Toman, R. and Massanyi, P. (1997). Structural changes in testis and epididymis after administration of cadmium. J Reprod. Fertil. 19, 309-319.

Trigg, P. I. and Kondrachine, A. V. (1998). Parasite biology, pathogenesis and protection. In Malaria: Sherman, I. W. (ed.) ASM press Washington DC; 11-22.

Warhurst, D. C. and Robinson, B. L. (1996). Pigmentation abnormalitics with antimalarial drugs with reference to chloroquine. A. M. A. Archives of Dermatology, USA, 96, 551-563.

Wernsdorfer, W. H. and McGregor, I. (1988). Malaria: In Principles and Practice of malariology. Churchhill Livingstone Edinburgh; 1128-1179.

Winstanley, P. A, Breckenridge, A. M., (1987). Malaria mortality. Ann. Trop. Med. Parasitol. 81,619-622.

World Health Organisation. (1990). Practical chemotherapy of malaria. Techn. Rep. Ser; No. 805. Geneva.

Wrobel, K. H., Keplet, M. and Shimmel, M. (1998). Quantitative evaluations of the tubular epithelium in the testis of the fallow dear. Reprod DOM. AMM. 28, 1-13.

Zukerman, Z., Rodriguez-Rigua, L. J. and Weiss, D. B. (1978). Quantitative analysis of the seminiferous epithelium in human testicular biopsies, and the relation of spermatogenesis to sperm density. Fertil. Steril. 30(4), 448-55. 